\title{
Accountability Perspective: Implementation and Reporting on Spending Fund of Papua Special Autonomy
}

\author{
John Agustinus \\ STIE Port Numbay Jayapura, Papua, Indonesia \\ Johnlecture69@yahoo.com
}

\begin{abstract}
The purposes of this research to identify (1) the Special Autonomy Law, local government regulations and compliance in determining financial performance or management of special autonomy funds, (2) compliance, supervision, accountability of special autonomy funds in determining accountability for the management of special autonomy funds, (3) knowledge related to education and experience on which to base effective management and efficient fund and provide benefits to the people of the province. The qualitative paradigm is used in this research and phenomenology methods. The findings showed: Implementation of accountability required a strong commitment from the governor and the entire staff of the agency concerned, ensure proper use of resources is consistent with legislation in force, indicating the level of achievement of goals and objectives that have been set. Oriented to achieving the vision and mission, as well as the results and benefits obtained, honest, objective, transparent, and accurate, Presenting success or failure in achieving the goals and objectives that have been set.
\end{abstract}

Keywords: Financial, Accountability, Special Autonomy and Qualitative

\section{Introduction}

The problem becoming the causal reason of special autonomy implementation in Papua province, according to Papua's Special AutonomyAssistance Team(Sumule, 2008:39-40), was originatedfrom the inability of the central governmentof Jakarta in providing welfare, prosperity, andrecognition of thefundamental rightsof the Papuan people. The conditions of Papuan society in education, economic, culture, social and politic are still very poor. Some of the peopleare stillaliveas if in the Stone Age. Fundamentalissuessuch asviolations ofhumanrightsanddenial of therights ofthe Papuan people's welfare are still notsettledfairly andwith dignity(Maidepa, 2006: 23). This situationhasresulted inthe emergence ofa variety ofdiscontentspreadthroughoutPapuaandexpressed ina variety of forms. Many oftheseexpressions are coped in violent means bythe centralgovernment, even by means of excessiveuseof militaryforce. The climaxisthe increasing number ofPapuanswanting to break awayfrom Unitary Sate of the Republic of Indonesia (NKRI)asanalternative toimprovewelfare. Determination ofthe problemin the policy of PapuaSpecial Autonomy Law No.21/2001 is as it has beendescribed above. Therefore, theobjective of this policyis notfarfrom theproblems facedby the Papua peopleand thewishes of the Papua people, whichincludesimproving the welfare ofthe Papua people, respecting forcivil rightsand basic human rights of Papua people, the freedomtomanage Papua government as well asequitabledistribution ofnatural resourcesfor the Papua people.

Special Autonomy of Papua Province is basically a wider authority for Papua people and governmentto administer and manage their region in the frame of Indonesia Republic. Wider authority means higherresponsibility for Papua government and people to establish their governance and manage the utilization ofPapua Province's natural resources for the Papua people welfare as part of Indonesia people based on the Law. This authority also means the right toempower its social and cultural potentials as well as economics potential of Papua people, including the effort todeliver equal role of the native Papua through their cultural/ethnic, religion, and women representatives. The principle of granting special autonomy for Papua Province is intended to bring about justice, upholding the rule of law, respect for human rights, the acceleration of economic development, improving the welfare and progress of the Papua people, in the framework of equality and balance with the progress of the other provinces. The implementation of Special Autonomy is obstructed by the unfinished implementation regulation of Law No. 21/2001. To implement the special autonomy, it needs a set of peraturan daerah propinsi/ perdasi (provincial regulation) and special regional regulation (peraturan daerah khusus/perdasus) that become the implementation regulation of Law No. 21/2001. Yet, so far, only one Perdasus is stipulated, while some others of fundamental Perdasi/Perdasus are not yet fixed: such as those which regulate special 
authority for provincial or regency/city government to establish the implementation of special autonomy as well as those which rule the development of prioritized sectors. In general, it happens because the slow process of legislation and lack of coordination among provincial government, provincial House of Representatives, and Papuan People's Council(MRP/Majelis Rakyat Papua). In practice, the implementation of special autonomy is mostly conducted using other less-binding law and regulation since it is not legitimated by provincial house of representative and MRP.

The Inhibitor of special autonomy implementation is a lack of effective coordination between the central government, provincial government, and the regency/municipality government. In some ways, Law No. 21/2001 is not in line with the Law No. 32/2004 on Regional Government and Law No. 33/2004 on Fiscal Balance. To harmonize the law, it needs a mechanism for coordination between the central, provincial governments, and regency / municipality governments. However, until now, there has not been an effective solution to establish a coordination mechanism, so that the authority and execution of development among the three levels of government is often overlaping. For example, Presidential Decree No. 5/2007, concerning the acceleration of development in Papua and West Papua, cannot be effectively implemented because of lack of coordination between the three levels of government. Moeller (2009); Anderson and Narus (1990); Child and Faulkner (1998); Das and Teng (1998); Zaheer and Vankatraman (1995) tried to find the role of trust and participation on financial performance. Moeller (2009) did not search for the consequence of the main value of trust on financial performance but the main value of trust is the accountability variable. This research fills the research gap of Moeller (2009) by adding accountability variable. It is based on Pekman's (1998), Penrose's (1959), and Barney's (1991) researches stating that public accountability has long term effect on financial performance. This is based on the statement of Wernerfelf (1984); Teece 1998); D’Aveni (1995); as well as Das, Toch Keaven; Teng Sui, (1998) who all mentioned that trust is inseparable with the accountability that is built to achieve positive objective of the financial performance.

The role of leadership and accountability is the acknowledgment and assumption of responsibility for actions, products, decisions and policies including the administration, regulation and its implementation within the scope of the role or position of employment, and emphasizing the obligation to report, explain and respond to the resulted consequences. The paradigm of the lack of financial management accountability involving mutual distrust is one of the crucial causes of people's understanding of the Special Autonomy Law for Papua. But the course of special autonomy implementation has not run optimally yet, a bit of problems descend its course such as authority distribution and the flow of funds that are not clear, the inconsistency of the central government and the Government of Papua up to conflict of interest and have the confidence (trust) will this policy, which since its inception has been waged by various parties as the "ultimate weapon" to solve the issues that have happened in Papua (Sumule, 2008), and other problems that the sectorial allocation of special autonomy fund from the provincial government for education and health sectors is not in accordance with the provisions yet.

The main problems of this research are: First, after 11 yearsof implementation, the special autonomy in Papua is still facing a number of problems that need improvement. Until now, the management of these funds is still inviting many questions, among others is in terms of legislation, allocation, transparency, monitoring, evaluation, and accountability (Hayadi, 2006: 11).Second, in terms of political point of view, special autonomy fund is intended as an answer to lagging Papua. So that the main problems in the implementation of special autonomy in Papua, there is no opportunity for the Papua people to organize and take care of themselves, the lack of freedom for the Papua people to self-govern and regulate the use of natural resources for the prosperity of the people, and no freedom to decide their own development strategies social, cultural, economic, political and according to the characteristics and peculiarities of human resources as well as the conditions and culture of Papua (Sumule, 2008: 41). Third, The emphasis of these regulations is the total correction of all deficiencies in the implementation of special autonomy fund, aiming to ensure that public money is managed economically, efficient, effective, transparent, accountable, and based on the public interest oriented (Mardiasmo, 2006: 17).The fourth, seen from the law point of view, there is a gap between the budget of APBD (Local Government Budget)and the 1945 Constitution of the Republic of Indonesia. The problem studied in this research is the study of the phenomenology of Accountability to the implementation and management of special autonomy fund. Furthermore, the study found a research question and purpose of the research, that is: "How is the accountability and reporting on the implementation of special autonomy fund that has been running for 11 years in Papua? 


\section{Literature Review}

A great attention to accountability entrusted by others (Saerang, 2001: 95), it means that the history of accountability has been initiated in conjunction with the existence of the community Gray, Anderson and Bernard Jenkins, (2003).The general concept states that accountability are two relationships (it can be individuals, groups, companies, governments, organizations, and others) which are directly and indirectly accountable to others in the form of things, actions, processes, products or inputs (Saerang, 2001:95) or the provision of information to the public on the performance of the parties concerned (Mardiasmo 2006: 21). Accountability is a process explaining one's actions and deeds to others who do not only accountable to themselves but also to other parties (Robert, 1991; Sinclair, 1995; Barbara, 2006). The doer is considered to be accountable if he is said to promise to do something and its implementation can be justified legally and morally (Robert, 1991; Sinclair, 1995; Parker and Gould, 2000; and Shearer, 2002). Accountability has two key elements, namely "account as well as the calculation of the account" which involves the author and the recipient of the account (Parker and Gould, 2000), as the obligation to provide an explanation in connection with the activities of the organization to those who need the information to explain the responsibility or the responsibility that is given (Salleh and Iqbal, 1995: 6).

Accountability has a relationship with the manager and the manager is at the heart of accountability relationships (Gray, Anderson and Bernard Jenkins, (2003)) so that all of the discussion about the concept of accountability cannot be separated by the presence of stewardship or manager (Saerang, 2001: 99).There is a diversity of mechanisms of accountability, Gray, Anderson and Bernard Jenkins, (2003) states that accountability can be measured through transparency, while Kovach et al. (2003) states organizational accountability measurement involves two key dimensions, namely the control of members and access to information. Accountability is the attitude and actions of decision-makers in government, the private and public sectors (civil society) that are responsible for their work to the public and institutional stakeholders. (Halim, 2008: 61). Then Lev (2001: 59-64) says accountability embodies the liability of any person or organizational unit, to manage the resources that have been given and controlled, in order to achieve the goal, through a medium in the form of periodic performance accountability report, accountability also can be described as the obligation to answer and explain the performance of the actions of a person or entity to which the parties have the right to ask for answers or information from a person who has been given the authority to manage a particular resource.

Accountability is the sides of the attitude and character of human life includes a person's internal accountability and someone's external accountability (Siradjudin and Aslam, 1995). Internal accountability is also called spiritual accountability. It is not just there is no theft and environmental sensibility, but more than that it is such feelings of shame in doing something that violates the provisions and so on. A person's external accountability environment is his accountability to his environment in this case to both formal (boss) and informal (community). Ledvina (1991: 62) says that accountability is an evolution of the activities carried out by an officer whether he is still on the track of his authority or has been out much of the responsibility and authority. Once a financial management system is established, it needs to prepare a tool to measure the performance and control the government to prevent KKN (corruption, collusion, and nepotism), lack of legal certainty and political stability, and lack of clarity of direction and policy development (Mardiasmo, 2002: 65 ). Theory analysis of financial performance (Kane and Johnson, 1995) is an overview of the financial performance achievement level in implementing an organization's activity / program / policy in achieving the organization's objectives, outcomes of organization in realizing the strategic objectives of an organization, customer satisfaction, as well as its contribution to the development of economic and accountability to the public. Therefore, the research's flow of thought can be formulated as follows:

\section{Methodology}

A qualitative approach is a process of research and understanding based on a methodology that investigates social phenomena and human problems. In this approach, researcher created a complex picture, researching words, a detailed report of the views of informant, and conduct studies on the natural situation (Creswell, 1998: 15).Qualitative research is based on the concept of "going exploring" which involves in depth and oriented case study of a number of cases or a single case. Bogdan and Taylor (Moleong, 2002: 3) argues that qualitative methodology is a research procedure that produces descriptive data in the form of words written or spoken by people and observed behavior. The next stage is of the themes above are discussed in the Focus Group Discussion (FGD) whose participants are, 
religious leaders, community leaders, traditional leaders, women leaders, Lecturer, Education Foundation as well as NGOs. All FGD participants agreed to provide the same recommendations on accountability

Figure 1: Flow of Thought

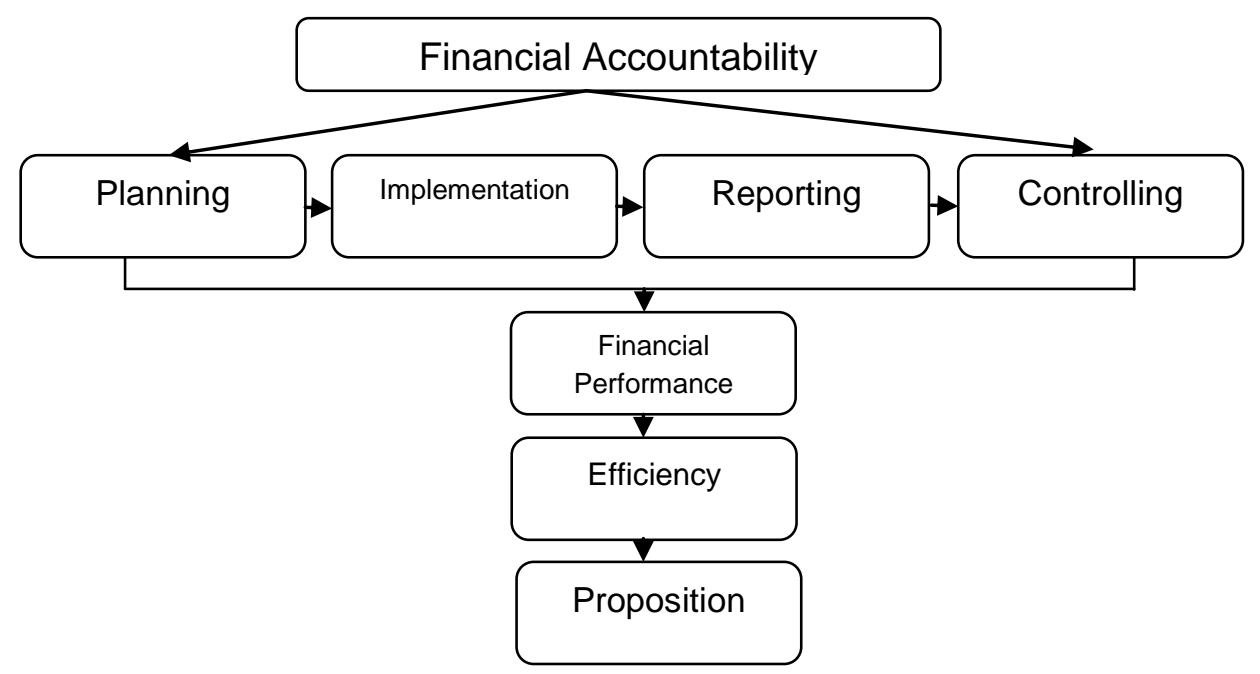

According to Spradley (2003), key informants can be characterized by their ability to provide accurate information it namely Purposive technique. Based on the theoretical background the researchers obtain four (4) key Informants and 8 (eight) supporting Informants.

Tabel 1: Key Informant

\begin{tabular}{|c|c|c|c|c|}
\hline No & Informant & Age & Area of Origin & Profession \\
\hline \multicolumn{5}{|c|}{ Key Informant } \\
\hline 1 & Informant 1 & 46 & Jayapura & $\begin{array}{l}\text { Head for Bureau of Finance of Papua } \\
\text { Province }\end{array}$ \\
\hline 2 & Informant 2 & 49 & Jayapura & $\begin{array}{l}\text { Head of Regional Development Planning } \\
\text { Agency of Papua Province }\end{array}$ \\
\hline 3 & Informant 3 & 50 & Jayapura & $\begin{array}{lll}\text { Head of } & \text { Education } & \text { and } \\
\text { InstructionDepartment Papua Province } & \end{array}$ \\
\hline 4 & Informant 4 & 46 & Jayapura & $\begin{array}{l}\text { Executive Directorof Direktur Ekesekutif ICS } \\
\text { (Institute For C Civil } \\
\text { Strengthening)Papua }\end{array}$ \\
\hline \multicolumn{5}{|c|}{ Supporting Informant } \\
\hline 5 & Informant 5 & 65 & Jayapura & Head of Christian Education Foundation \\
\hline 6 & Informant 6 & 48 & Jayapura & Head of Islamic Education Foundation \\
\hline 7 & Informant 7 & 55 & Jayapura & Lecturer and Head of College \\
\hline 8 & Informant 8 & 51 & Jayapura & Society Representative \\
\hline 9 & Informant 9 & 60 & Jayapura & Tokoh Agama \\
\hline 10 & Informant 10 & 40 & Jayapura & Cultural/Ethnic Representative \\
\hline 11 & Informant 11 & 42 & Jayapura & TV Journalist \\
\hline 12 & Informant 12 & 49 & Jayapura & Newspaper Journalist \\
\hline
\end{tabular}

Source: Primary data

The analysis used is the phenomenological analysis proposed by Weber (1960 In which the phenomenology is associated with the concept of rational action by analyzing the meanings that are behind the actions of individuals who promote the establishment of the social phenomena, and reveal why there is deviation of autonomy special fund management.

\section{Result and Disscusion}

Identify the entire understanding and quantitative description of data management of special autonomy funds obtained themes Implementation and Reporting Accountability In the special autonomy funds are presented in the following table: 
Table 2: Implementation and Reporting Accountability in the Special Autonomy Funds

\begin{tabular}{|c|c|c|c|}
\hline No & Financial Performance & Accountability Theme & Theme Classification \\
\hline 1. & Special Autonomy LawNo 21 of 2001 & $\begin{array}{l}\text { Improving the welfare of } \\
\text { Papuans }\end{array}$ & Benefit \\
\hline 2. & $\begin{array}{l}\text { Province Regional Regulation No } 1 \text { of } \\
2007\end{array}$ & Management priority of SAF & $\begin{array}{l}\text { Education as Main } \\
\text { Priority }\end{array}$ \\
\hline 3. & Regional RegulationNo 5 of 2006 & $\begin{array}{l}\text { Mandating } 30 \% \text { of } \mathrm{SAF} \text { for } \\
\text { education }\end{array}$ & Education Budget \\
\hline 4. & $\begin{array}{l}\text { Regulation of Minister of Internal } \\
\text { Affairs No. } 13 \text { of } 2006\end{array}$ & $\begin{array}{l}\text { The Principles of Regional } \\
\text { Financial Management }\end{array}$ & $\begin{array}{l}\text { Regional Financial } \\
\text { Management }\end{array}$ \\
\hline 5 & $\begin{array}{l}\text { Regulation of Minister of Internal } \\
\text { Affairs No. } 13 \text { of } 2006 \text { and Government } \\
\text { Regulation No.24 of } 2005\end{array}$ & $\begin{array}{l}\text { Preparing Financial Statement } \\
\text { in accordance with Government } \\
\text { Accounting Standard }\end{array}$ & Financial Information \\
\hline 6 & $\begin{array}{l}\text { Added by Perdasi No } 1 \text { th } 2007 \text { and } \\
\text { Perda No } 5 \text { Tahun } 2006\end{array}$ & $\begin{array}{l}\text { Mandating efficiency and } \\
\text { effectivity }\end{array}$ & Achievement \\
\hline 7 & $\begin{array}{l}\text { Head of Local Government is regional } \\
\text { financial manager }\end{array}$ & $\begin{array}{l}\text { Governor as Special Autonomy } \\
\text { manager }\end{array}$ & Person in Charge \\
\hline 8 & $\begin{array}{l}\text { Special Autonomy Fund amounted to is } \\
\text { more than sufficient to develop } \\
\text { education in Papua province }\end{array}$ & & Sufficient \\
\hline 9 & $\begin{array}{l}\text { Education budget is prioritized to } \\
\text { improving the quality of public } \\
\text { education, not for salaries of educators, } \\
\text { administration fees, honoraria, travel } \\
\text { expenses of employees, the cost of food } \\
\text { and beverage employees, and other } \\
\text { bureaucratic expenditures in the } \\
\text { routine expenditure group. }\end{array}$ & Quality of society education & Quality \\
\hline 10 & $\begin{array}{l}\text { All provisions of Regional Regulation } \\
\text { are properly implemented; education } \\
\text { in Papua is expected to run optimally. }\end{array}$ & $\begin{array}{l}\text { A set of financial management } \\
\text { rules }\end{array}$ & Financial Performance \\
\hline 11 & $\begin{array}{l}\text { Education sector has been set as a } \\
\text { priority program, but education is not } \\
\text { a priority }\end{array}$ & & Not maximum yet \\
\hline 12 & $\begin{array}{l}\text { The budget allocation for education in } \\
\text { Papua is only at } 3 \text { percent to } 5 \text { percent } \\
\text { of the total budget, and it also does not } \\
\text { reach } 30 \% \text { of the special autonomy } \\
\text { fund }\end{array}$ & & Not maximum yet \\
\hline
\end{tabular}

Source: Primary data

The research findings result in research propositions.

- Compliance, supervision, and accountability of special autonomy fund determine accountability for the management of special autonomy fund

- Education and experience that become the base of efficient and effective fund management and provide benefits to society of Papua province, A model of accountability is derived as follows: 
Figure 2:Accountability Perspective: Implementation and Reporting on Spending Fund of Papua Special Autonomy

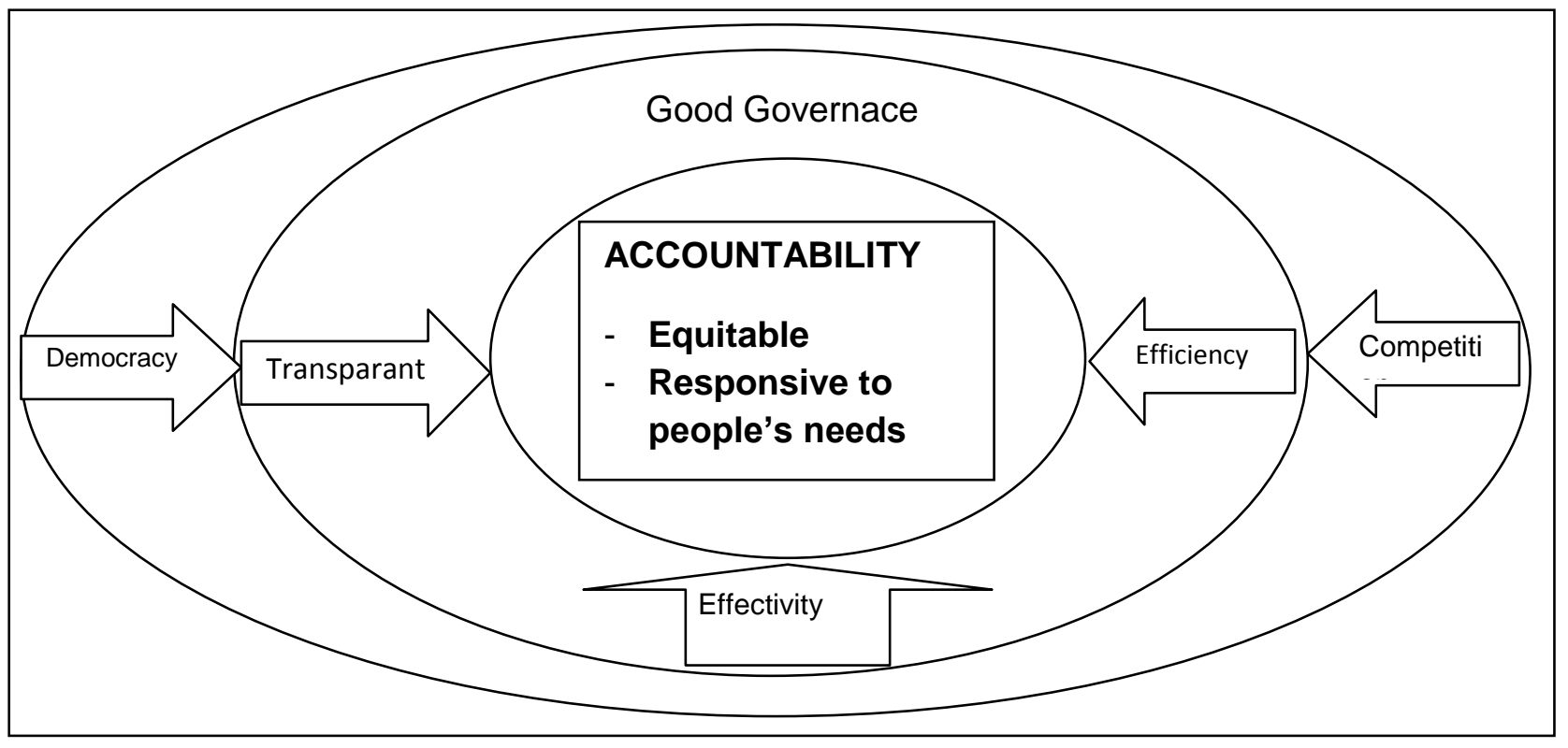

\section{Conclusion}

Performance-oriented special autonomy fund management shows performance accountability. Accountability performance embodies Papua provincial government's obligation to be responsible for either the Papua provincial success or failure of the implementation of special autonomy fund management in achieving the goals and objectives periodically measured with a set of performance indicators. In the performance-oriented special autonomy fund management, there is a correlation between the strategic objectives to be achieved and the amount of fund allocated. This correlation can facilitate the comprehensive planning, implementation and reporting, both in terms of objective achievement, formulation and implementation of programs, activities, as well as the process of enacting and controlling the budget and performance analysis. This will further facilitate the evaluation and examination conducted by the internal audit function.

Internal audit on the budget and government operations intended to test whether the special autonomy fund management has been implemented in accordance with the regulations that have been set. Internal audit is also intended to assist management in carrying out their responsibilities in achieving performance. By obtaining efficient and effective financial performance, the Papua provincial government is able to be responsible for resource management and policy implementation is entrusted in order to achieve the goals set by the accountability media in the form of periodic reports of performance accountability. Therefore, the concept of accountability which is given in this study Papua's provincial government is able to be responsible for the management of special autonomy fund entrusted and able to explain the achievement of results in accordance with the mandate of the Special Autonomy Law. Accountability implementation requires strong commitment of the governor and all staffs in the related institutions. They should assure the utilization of resources which is consistent with the applicable law and regulation. It should confirm the goal objective achievement level as well as the obtained result and benefit/advantage. It must be truthful, objective, transparent, and accurate. Also, it should present the achievement/failure to attain the determined goal and objective.

\section{References}

Abdullah, E. (1979). Agama, Etos Kerja dan Perkembangan Ekonomi. Jakarta: LP3ES.

Anderson, J. \& Narus, J. (1990). A model of distributor firm and manufacturer working partnerships. Journal of Marketing, 54(1), 42-58.

Barbara, S. (2006). Mission Statement Quality and Financial Performance. European Management Journal, 24(1), 86-94, 20062005 Elsevier Ltd. All rights reserved. 
Barney. (1991). Knowledge and Accountability: Outside's Directors'contribution in the corporate value chain. Centre for Innovation, Research and Competence in the Learning Economy (CIRCLE) Lund University P.O. Box 117, Sölvegatan 16, S-221 00 Lund, SWEDEN http://www.circle.lu.se/publications ISSN 1654-3149

Child, J. \& Faulkner, L. (1998). Strategies of Cooperation: Managing Alliances, Networks and Joint Ventures. Oxford University Press, Oxford.

Constitution of Republic Indonesia, No 21. (2001). Special Autonomy for Province Papua.

Creswell, J. (1998). Mix Methods Research. University of Nebraska-Lincoln, USA. P.15

Das, T. K. \& Teng, S. (1998). Between trust and control: developing confidence in partner cooperation in alliances.Journal of Intellectual CapitalAcademy of Management Review, 23(3), 491-512.

D'Aveni. (1995). Coping with hypercompetition: utilizing the new 7s's framework. Journal Academy of Management Executive, 9(3), 45-60.

Gray, A. \& Jenkins, B. (2003). Codes of accountability in the New Public Sector. Accounting Journal, 6(3), 52-67 (C) MCB University Press, 0951-3574.

Halim, A. (2008). Regional Financial Management. Managing Regional Financial. STIM YKPN, Yogyakarta.

Hayadi, K. (2006). Analysis of Performance of Midwife at Center of Society Health on Serving Antenatal in South Bengkulu, KMPK, WPS N0 11 April 2007 Yogyakarta

Kane \& Johnson. (1995). Planning, Budgeting, Actuating, Administration and Controlling of Regional Financial Training and Education, Financial Management Practical (Financial Management Certified). Regulation of Ministry of Home Affairs 29/2002, 2005).

Kovach, H., Neligan, C. \& Burali, S. (2003). Power Without Accoutability? The Global Accoutability Report 1, One World Trust, London, pdf download available at: www.oneworldtrust.org/htmlGAP/report.

Lev, B. (2001). Intangibles: Management, Measurement, and Reporting. Brookings Institution, Washington, DC.

Ledvina, C. V. (1991). Accountability, Corruption and Democracy: A Clarification of Concepts, (in the Asian Review of Public Administration. Journal of Accounting, 3(2), December 1991)

Mardiasmo. (2002). Otonomi dan Manajemen Keuangan Daerah: Ed. II. Penerbit Andi Offset Yogyakarta, Hal 65.

Mardiasmo. (2006). Forming Transparency and Public Accountability Through Public Accounting: Tools for Good Governance. Jurnal Akuntansi Pemerintahan, 2(1), 1 - 17.

Maidepa, R. (2006). DevelopmentSynthesis in Papua. Team of Papua Capacity.

Moeller, K. (2009). Intangible and financial performance: causes and effects. Journal of Intellectual Capital, 10(2), 224-245 q Emerald Group Publishing Limited 1469-1930.

Parker, L. \& Greame, G. (2000). Changing Public Sector Accountability: Critiquing New Directions. Blackwell Publiser.

Parsons, T. \& Shils, E. (1952). Toward a General Theory of Action, Cambridge University Press, Cambridge, MA.

Pekman, J. (1998). Capital District Health Authority Research Ethics Board. http://www.governance.uottawa.ca/english/overview/o_defi.htm (accessed August 25th, 2003) Cited in McDonald q.v. See also D. Zussman, Proposed Governance Structure for the Canadian Institutes of Health Research (Ottawa: Public Policy Forum, 1999). Version 2.11 August 28th, 2003

Penrose. (1959). Examining the penrose effect in an international business context: the dynamics of japanese firm growth in u.s. Industries. We are grateful to Richard Levin, Alvin Klevorick, Richard Nelson, and especially Sidney Winter for providing us with the data from their paper in Brookings Papers on Economic Activity (1987). Published: 2003 URL: http://www.business.uiuc.edu/Working_Papers/papers/03-0113.pdf

Regulation of Regional of Province Papua No 3/2004: Fundamentals of Regional Financial Management. Goverment of Province Papua,Regulation of Regional of Province PapuaNo. 5/2006, Education Development in Province Papua

Robert, J. (1991). The Possibilities of Accountability. Accounting, Organizaation, and Society, 16(4), 355368

Siradjudin, S. H. \& Aslam, I. (1995). Accoutability; The Endless Phropecy. Asian AND Pasific Development Centre

Saerang, D. P. E. (2001). Accountability and Accounting in a Religius Organization: an Interactive Ethnographic Study of the Pantecostal Church of Indonesia. Disertation University Wollonggong. 
Spradley, J. P. (2003). Metodologi Etnografi. Penerjemah Misbah Zulfah Elizabeth. Yogyakarta. Penerbit; PT. Tiara Wacana

Sumule, A. (2008). Finding a central ways: Special Automony Provonce Papua. JayapuraCopyright (C) 2003, Agus Sumule, Penerbit Yayasan ToPanG, Jalan Cenderawasih C-65, Manokwari, Papua 98314 (Hal 23-24).

Sinclair, A. (1995). The Chamelon of Accountability; Forms and Discourses. Accouting, Organization, and Society, 2, 219-237.

Shearer, T. (2002). Ethics and Accountability. Accounting, Organization, and Society, 3, 541-573.

Teece, D. (1998). Capturing value from knowledge assets: the new economy, markets for know-how, and intangible assets. California Management Review, 40(3), 55-79.

Weber, M. (1960). Sekte-sekte Protestan dan Semangat Kapitalisme dalam Taufik

Wernerfelt. (1984). A resource-based view of the firm. Strategic Management Journal, 5(2), 171-80.

Zaheer, A. \& Venkatraman, V. (1995). Relational governance as an interorganizational strategy: an empirical test of the role of trust in economic exchange. Strategic Management Journal, 16(5), 373-92. 